\title{
Crustal stress regime in Italy
}

\author{
Paola Montone $\left({ }^{1}\right)$, Alessandro Amato $\left({ }^{1}\right)$, Alberto Frepoli $\left({ }^{1}\right)$, Maria Teresa Mariucci $\left({ }^{1}\right)$ \\ and Marco Cesaro $\left(^{2}\right)$ \\ ${ }^{1}$ ) Istituto Nazionale di Geofisica, Roma, Italy \\ ${ }^{2}$ ) AGIP S.p.A., S. Donato Milanese, Milano, Italy
}

\begin{abstract}
In order to obtain a reliable map of the present-day stress field in Italy, needed to better understand the active tectonic processes and to contribute to the assessment of seismic hazard, in 1992 we started to collect and analyze new data from borehole breakouts in deep oil and geothermal wells and focal mechanisms of earthquakes $(2.5<M<5)$ occurred in Italy between 1988 and 1995. From about 200 deep wells and 300 focal mechanisms analyzed to date, we infer that: the internal (SW) sector of the Northern Apenninic arc is extending with minimum compressional stress $\left(S_{h \min }\right)$ oriented $\approx \mathrm{ENE}$, while the external front is thrusting over the Adriatic foreland $\left(S_{h \min } \approx \mathrm{NW}-\mathrm{SE}\right)$. The entire Southern Apennine is extending in NE direction (from the Tyrrhenian margin to the Apulian foreland) and compression (in the foredeep) is no longer active at the outer (NE) thrust front. Between these two arcs, an abrupt change in the tectonic regime is detected with directions of horizontal stress changing by as much as $90^{\circ}$ in the external front, around latitude $43^{\circ} \mathrm{N}$. Along the Ionian side of the Calabrian arc the stress directions inferred from breakouts and focal mechanisms are scattered with a hint of rotation from N-S $S_{h \min }$ close to the Southern Apennines, to $\sim$ E-W directions in the Messina Strait. In Sicily, a NW-SE direction of $S_{H \max }$ is evident in the Hyblean foreland, parallel to the direction of plate motion between Africa and Europe. A more complex pattern of stress directions is observed in the thrust belt zone, with rotations from the regional trend (NW - directed $S_{H \max }$ ) to NE oriented $S_{H \max }$. A predominant NW direction of $S_{H \max }$ is also detected in mainland Sicily from earthquake focal mechanisms, but no well data are available in this region. In the northern part of Sicily (Aeolian Islands) a $\sim \mathrm{N}-\mathrm{S}$ direction of $S_{H \max }$ is observed.
\end{abstract}

Key words Italy - active stress - borehole breakout - seismicity

\section{Introduction}

A detailed map of active stress in the crust is fundamental to constrain geodynamic models of the Italian peninsula and to understand the active tectonic processes. Both numeric and laboratory modeling like those recently proposed for this region (see e.g., Bassi and Sabadini, 1994; Giunchi et al., 1996; Faccenna et al., 1996) would benefit from a better knowl-

Mailing address: Dr. Paola Montone, Istituto Nazionale di Geofisica, Via di Vigna Murata 605, 00143 Roma, Italy; e-mail: montone@ing750.ingrm.it edge of the present-day stress field. Also, active stress data are invaluable in seismotectonic zoning and can be used to identify and investigate local stress perturbations that may localize seismicity (Zoback, 1993). This is particularly important in Italy for seismic zones that are out of the main fault belt of the peninsula, where the largest $(M \sim 7)$ earthquakes nucleate, but are highly hazardous as well. In addition, an accurate knowledge of the active stress field is useful for oil and geothermal exploitation, since it yields important indications on the development of induced hydraulic fractures.

The currently available compilations of stress data are based on incomplete and inhomogeneous data sets (Mueller et al., 1992; Rebai et al., 1992). Borehole breakouts are almost completely absent in the Italian data base. In 


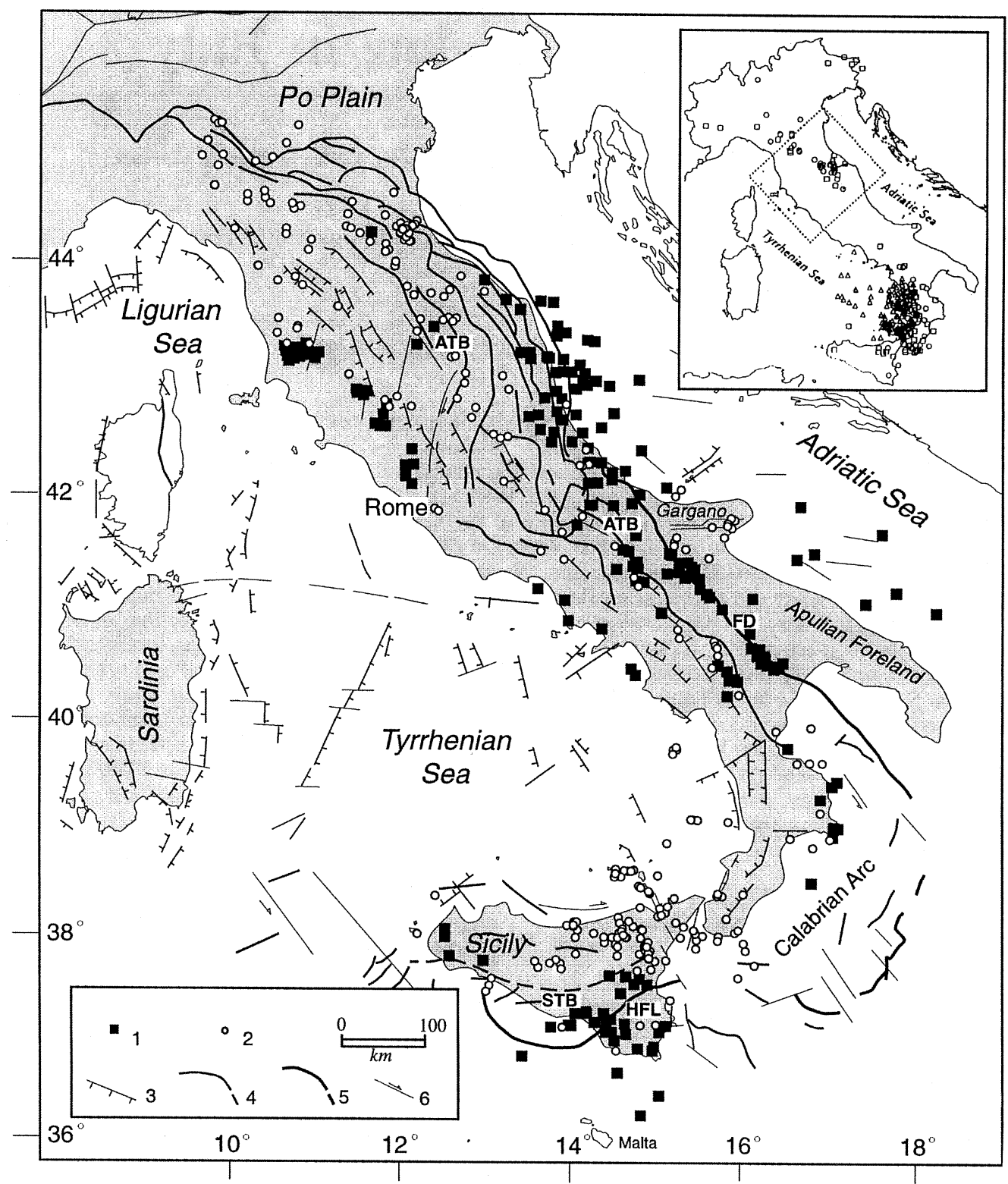

Fig. 1. Location of the deep wells analyzed for stress determination, compared to the distribution of the earthquakes that occurred between 1988 and $1995(2.5<M<4.8)$ for which we have determined focal mechanisms. Legend: 1) deep wells location; 2) epicenters; 3) normal faults; 4) major overthrusts of the Apennines; 5) front of the «plastic» allochthonous sheet in the Southern Apennines and Sicily; 6) strike-slip and undetermined faults. FD = Apenninic foredeep; ATB = Apenninic thrust belt zone; STB = Sicily thrust belt zone; HFL = Hyblean foreland. Tectonics modified from Patacca and Scandone (1987) and Bigi et al. (1990). In the upper right corner: epicenters of the deep (> $30 \mathrm{~km}$ ) earthquakes, (modified from Selvaggi and Amato, 1992). 
the compilation of the World Stress Map (Zoback, 1992), for instance, only one breakout measurement is reported for the entire Italian region, the active stress data are mostly $P$ or $T$ axes from focal plane solutions, that are often poorly constrained.

The most reliable information on the active stress distribution in Italy derives from the CMT focal solutions (although earthquakes are indicators of strain) computed by Harvard University, but these are available only for a few, strong $(M>5.5)$ earthquakes which occurred in the past twenty years (Jackson and McKenzie, 1988; Pondrelli et al., 1995). For earthquakes that occurred between 1908 and 1980, fault plane solutions from bulletin polarity data $(3.5<M<7.0)$, are available from the literature (Gasparini et al., 1985; Anderson and Jackson, 1987; Westaway, 1987). These results are often not well constrained, all the solutions computed by Gasparini et al. (1985) have ' $\mathrm{C}$ ' or ' $\mathrm{D}$ ' quality (low quality) in the ranking system of the WSM (see Zoback, 1992).

In order to obtain a more reliable and detailed map of present-day stress in Italy, in the past four years we have systematically collected and analyzed breakouts from deep wells and focal mechanisms of small events $(M<5)$ which occurred in the past eight years (fig. 1). In this paper, we review all the data published to date on both types of stress indicators (Montone et al., 1992; Cesaro, 1993; Frepoli et al., 1993; Amato et al., 1995; Montone et al., 1995; Ragg et al., 1995; Frepoli and Amato, 1997). In addition, we report new data from borehole breakouts in Central-Northern Apennines and in the Calabria region (about 60 stress directions) and from earthquake focal mechanisms (Frepoli and Amato, 1996).

To date, about 200 deep wells $(0-7 \mathrm{~km}$ depth) were analyzed (fig. 1), 120 of which gave valuable results (directions. of $S_{H \max }$ and $\left.S_{h \text { min }}\right)$. Data from wells in Sicily were analyzed by Cesaro (1993) and Ragg et al. (1995). In addition, about 300 directions of compressional $(P)$ and tensional $(T)$ axes of recent (post 1988) earthquakes are available, to be compared with CMT and polarity solutions from previous studies.

\section{Breakout analysis}

\subsection{Method}

Breakouts are localized shear failures on borehole walls, which occur when wells are drilled in an anisotropic stress field, and they yield horizontal stress directions $-S_{H \max }$ and $S_{h \min }$ (Bell and Gough, 1983; Zoback, 1992).

Since no shear stresses can exist in the plane of the Earth's surface, one of the principal stresses in the upper crust should be oriented approximately perpendicular to it (Anderson, 1951).

In this paper, as in all the papers published on this topic (see Zoback, 1992 and references therein), our results and interpretations are based on this assumption (see also McGarr and Gay, 1978). In most cases this is supported by the inversion of focal mechanisms that shows stress axes generally within $20^{\circ}$ from the vertical.

The four-arm caliper readings that we use to measure the breakout zones are reported as either digital curves or paper field logs.

The criteria that we use to recognize a breakout zone are those described in Plumb and Hickman (1985) relative to: tool rotation (must cease in breakout zones); the enlargement of one caliper with respect to the other one, equal to the bit size; the hole azimuth, that must be different from the breakout azimuth by more than $10^{\circ}$; the hole deviation from the vertical (not more than $15^{\circ}$ and not less than $0.5^{\circ}$ ).

Breakouts, using the paper field logs, are recognized when the criteria described above are satisfied for a minimum length of $1 \mathrm{~m}$ and a minimum difference of $1.3 \mathrm{~cm}$ between the two caliper arms. Particular attention was paid to the identification of other causes of borehole ellipticity, such as key seats and washouts, due to erosional action of the drill pipe in deviated wells and to caving of the entire perimeter of the well, respectively. Neither key seats or washouts were used in the computation of the stress directions. A weight was assigned to each breakout interval, according to its geometry and to the tool rotation trend before, within and after the breakout zone. Length and azimuth of each breakout zone are input into a Fortran program that calculates the mean 
breakout direction (corresponding to $S_{h \min }$ ) and its standard deviation both for cumulative breakout length and for number of observations.

The analysis of digital logs, performed with a package of Fortran codes, uses the same basic criteria for breakout discrimination as the paper log analysis, scanning the curves of the well geometry that are generally sampled at $0.1 \mathrm{~m}$ (or sometimes less). There are two main differences between digital and paper logs analysis, namely: a) the first is somehow more «objective» than the second, relying on cut-off criteria set a priori (the analysis of paper logs is heavily based on the operator's experience, that might include pre-conceived notions on expected stress directions); b) digital analysis does not consider the rotation before, during and after the logging tool comes across a breakout zone (this is a strongly discriminating feature for traditional paper log analysis, see Plumb and Hickman, 1985). From the two orthogonal calipers, the program computes a suite of nine «synthetic» calipers, one every $22.5^{\circ}$, assuming the well has an elliptical cross-section. This gives a representation of the shape of the well section (fig. 2). Then, a series of cut-off values are defined for each well (fig. 3), based on ellipticity (defined as the ratio between maximum and minimum caliper arms, CIN); normalized ellipticity; perimeter index (defined as the ratio between the actual borehole perimeter, considered as an ellipse, and the bit size circular perimeter, PERI); the difference between the minimum caliper arm and the bit size (used to discriminate breakouts from washouts); and the ratio between the actual borehole perimeter, considered as an ellipse, and the minor borehole axis perimeter (PERC). The use of slightly different cut-off values accounts for the remarkable differences in the ellipticity of the analyzed wells. For instance, higher cut-off values are applied to wells that are largely caved, in order to exclude from the computation of the stress directions large quantities of washout zones. Conversely, in wells drilled in high strength rocks, that are characterized by a circular section for most of their length, we adopted lower cut-off values.

A breakout zone is defined when at least four adjacent points (one every $0.1 \mathrm{~cm}$ ) satisfy

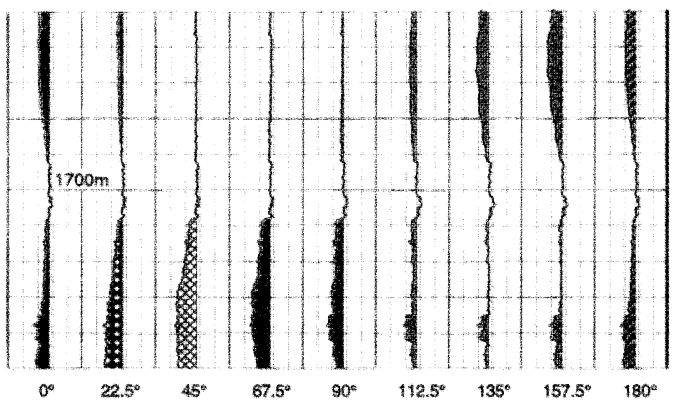

Fig. 2. Nine «synthetic» oriented calipers from $0^{\circ}$ to $180^{\circ}$. In the upper part an example of breakout zone oriented NNW-SSE; in the lower part an example of washout zone.

the cut-off values described above. All the selected breakout zones are then put into another program that determines the breakout mean direction (parallel to $S_{h \min }$ ) and the standard deviation, similarly to what is done in the paper $\log$ analysis. For the digital data, breakout zones are also plotted with frequency diagrams along the well section to allow us to check how the breakout azimuth varies depending on depth, lithology, dip of the bedding planes, and fault zones (fig. 3).

To attribute a quality value to each well we adopted the quality ranking system proposed by Zoback (1992) for the WSM: from ' $A$ ' quality for the best data to ' $E$ ' quality for discarded wells, depending on total breakout length and standard deviation of the mean direction (see table I).

Table I. Ranking criteria adopted to evaluate statistical significance of breakout inferred stress directions.

\begin{tabular}{ccccc}
\hline \hline \multirow{2}{*}{ Length } & \multicolumn{5}{c}{ Standard deviation } \\
\cline { 2 - 5 } & $<12^{\circ}$ & $<20^{\circ}$ & $<25^{\circ}$ & $>25^{\circ}$ \\
\hline $\mathrm{Q}=300 \mathrm{~m}$ & $\mathrm{~A}$ & $\mathrm{~B}$ & $\mathrm{C}$ & $\mathrm{D}$ \\
$100-300 \mathrm{~m}$ & $\mathrm{~B}$ & $\mathrm{C}$ & $\mathrm{D}$ & $\mathrm{E}$ \\
$30-100 \mathrm{~m}$ & $\mathrm{C}$ & $\mathrm{D}$ & $\mathrm{E}$ & $\mathrm{E}$ \\
$0-30 \mathrm{~m}$ & $\mathrm{D}$ & $\mathrm{E}$ & $\mathrm{E}$ & $\mathrm{E}$ \\
\hline
\end{tabular}




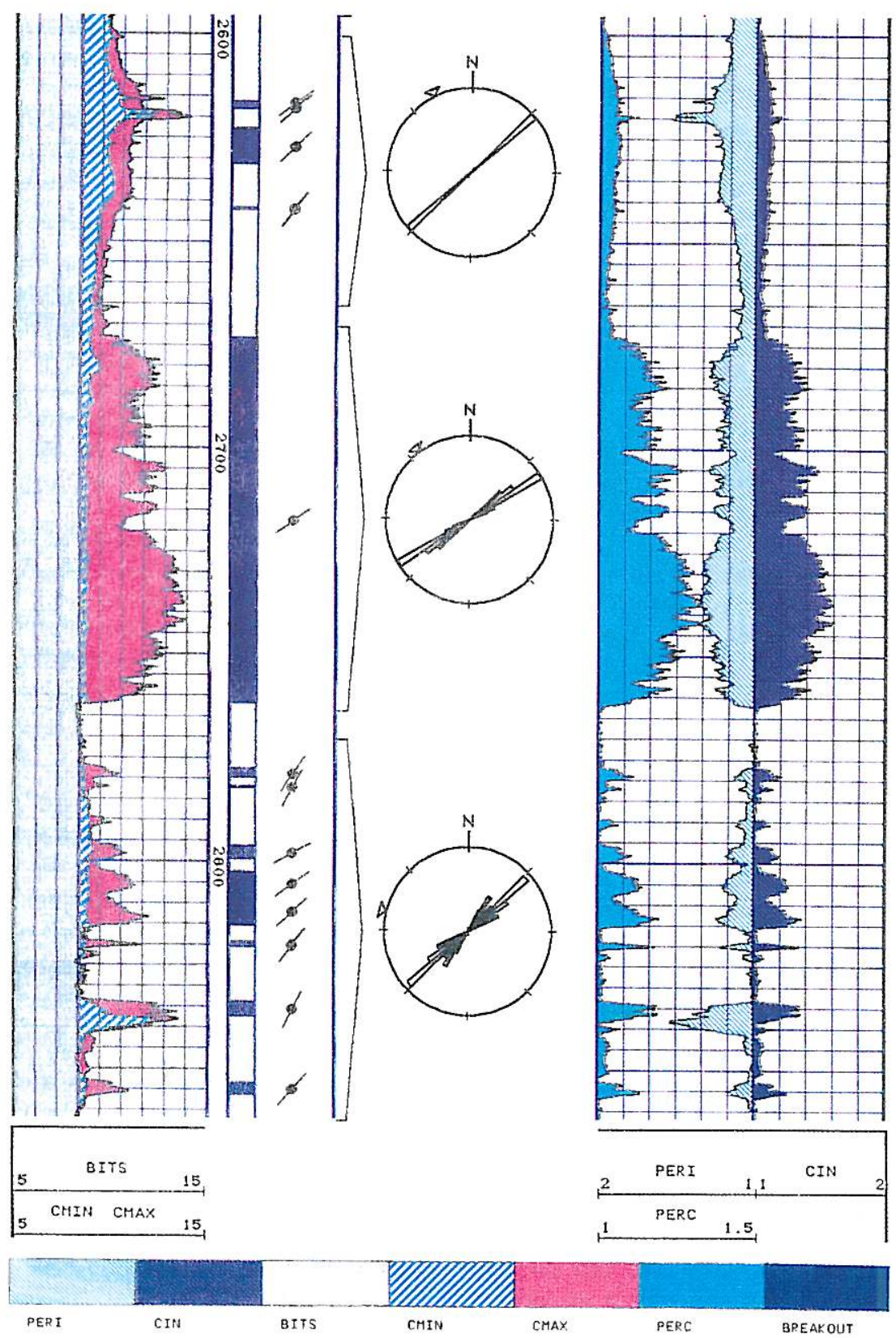

Fig. 3. Central column: azimuthal frequency diagrams of 3 breakout intervals (2600-2650 $\mathrm{m} ; 2670-2770 \mathrm{~m}$; 2780-2860 m). The left column shows the hole geometry with the two calipers (CMIN and CMAX) and the bit size (BITS). Right column: curves of parameters used to discriminate breakouts (PERI, PERC, CIN). Symbols: BITS = drilling diameter (inch); CMIN = minimum caliper (inch); CMAX = maximum caliper (inch); PERI $=$ borehole/bit size perimeter index; $\mathrm{PERC}=$ borehole/minor axis perimeter index; $\mathrm{CIN}=$ major axis length/minor axis length ellipticity index. 


\subsection{Breakout analysis - results}

\subsubsection{Northern and Central Apennines}

We have analyzed 67 new wells (fig. 4) in the Central-Northern Apennines and Adriatic Sea (between $42^{\circ} \mathrm{N}$ and $44^{\circ} \mathrm{N}$ latitude). Only 53 boreholes are useful to determine $S_{h \text { min }}$ directions; 14 wells were classified as ' $E$ ' (the worst data quality $=$ no stress indications) because of tool problems, such as a too low deviation from the vertical (less than $0.5^{\circ}$ ), or because the computed results have a very high standard deviation. In some wells no ovalization was detected: 3 of them are in the northern sector of the study area (two on land and one offshore), the other 5 are offshore, 4 of which are around $43^{\circ} \mathrm{N}$.

In this paper we present preliminary results of the breakout analysis of these 67 wells, obtained only from paper logs; more detailed analysis using digital $\operatorname{logs}$ are currently in progress (Mariucci et al., in preparation). These will allow us to discriminate anomalous stress directions possibly related to different stratigraphic and tectonic units, and therefore to assess the most reliable regional stress direction.

Most of the wells are located in the foredeep region (fig. 1), only two neighbouring wells were analyzed in the belt (Central Italy). The breakout results point out quite different $S_{h \min }$ orientations for these two wells: N10E and N70E, with quality $\mathrm{C}$ and $\mathrm{D}$, respectively (fig. 4). Perhaps these directions are affected by the presence of local tectonic structures, a more detailed analysis using digital data is currently in progress. These two wells have penetrated the Umbria-Marche basin units and have reached the Permo-Triassic formations like the «Anidriti di Burano», and in one case the «Verrucano». It is interesting to note that the two largest earthquakes that occurred in this region (the 1979 Norcia and 1984 Perugia-Gubbio earthquakes) both have normal faulting mechanisms, with $T$-axes oriented N79E and N39E, according to the CMT catalogue.

For the wells located in the northern sector of the Po plain-Adriatic foredeep zone (fig. 4), we find breakouts $\left(=S_{h \text { min }}\right)$ with a prevailing direction NW-SE (in the range from N24W to N60W). These results come from nine wells, five of which with quality ' $A$ ' to ' $C$ ' and four classified as ' $\mathrm{D}$ '. The NW-SE direction is the most evident north of $43^{\circ} \mathrm{N}$. More to the south we find $S_{h \text { min }}$ oriented NE-SW (between N22E and $\mathrm{N} 55 \mathrm{E}$ ). This was obtained from the breakouts of 15 wells: five of quality ' $A$ ' or ' $B$ ', three with quality $C$, and seven quality $D$ ).

In the area where we detected this abrupt change in the direction of $S_{h \text { min }}$ (fig. 4) there are some wells with breakout orientations almost E-W (two of them are classified ' $\mathrm{C}$ ' and two ' $D$ '). Three other wells with the same direction are located more to the south; they have $S_{h \min } \mathrm{N} 70-75 \mathrm{E}$ with quality 'A' and 'B' (two) or ' $\mathrm{C}$ ' (one).

Some deep wells, without a preferred geographical localization, have $S_{h \min }$ oriented N-S (fig. 4); two of them are on land (quality ' $C$ '), in the southernmost sector of the study area, but the largest part is offshore (three with quality ' $\mathrm{A}$ ', ' $\mathrm{B}$ ' or ' $\mathrm{C}$ ', and five with quality ' $\mathrm{D}$ ').

Two wells in the foredeep show two peaks of $S_{h \text { min }}$ : their location is different but their $S_{h \text { min }}$ directions are similar. In the deepest part of these boreholes, where a calcareous lithology is drilled, the principal breakout direction is N60W, whereas in the upper part $S_{h \min }$ is oriented N75E (in the well penetrating the Mio-Pliocene Flysch units) and N65E in the other one, where the Pliocene allochthonous units were drilled.

A $\sim$ NE orientation of $S_{h \text { min }}$, similar to that observed in the belt and south of $43^{\circ} \mathrm{N}$, was recognized in the Tyrrhenian back-arc region of Central Italy, around the Quaternary volcanoes of Latium and Southern Tuscany. Here, a NE to ENE $S_{h \min }$ was observed (fig. 4), in agreement with the inversion of focal mechanisms that indicate a NE-SW $\sigma_{3}$ direction (Montone et al., 1995).

\subsubsection{Southern Apennines}

In the Southern Apennines we have analyzed 64 wells from the Tyrrhenian coastal region to the Adriatic foreland (fig. 4). The results are described by Amato et al. (1995) and 


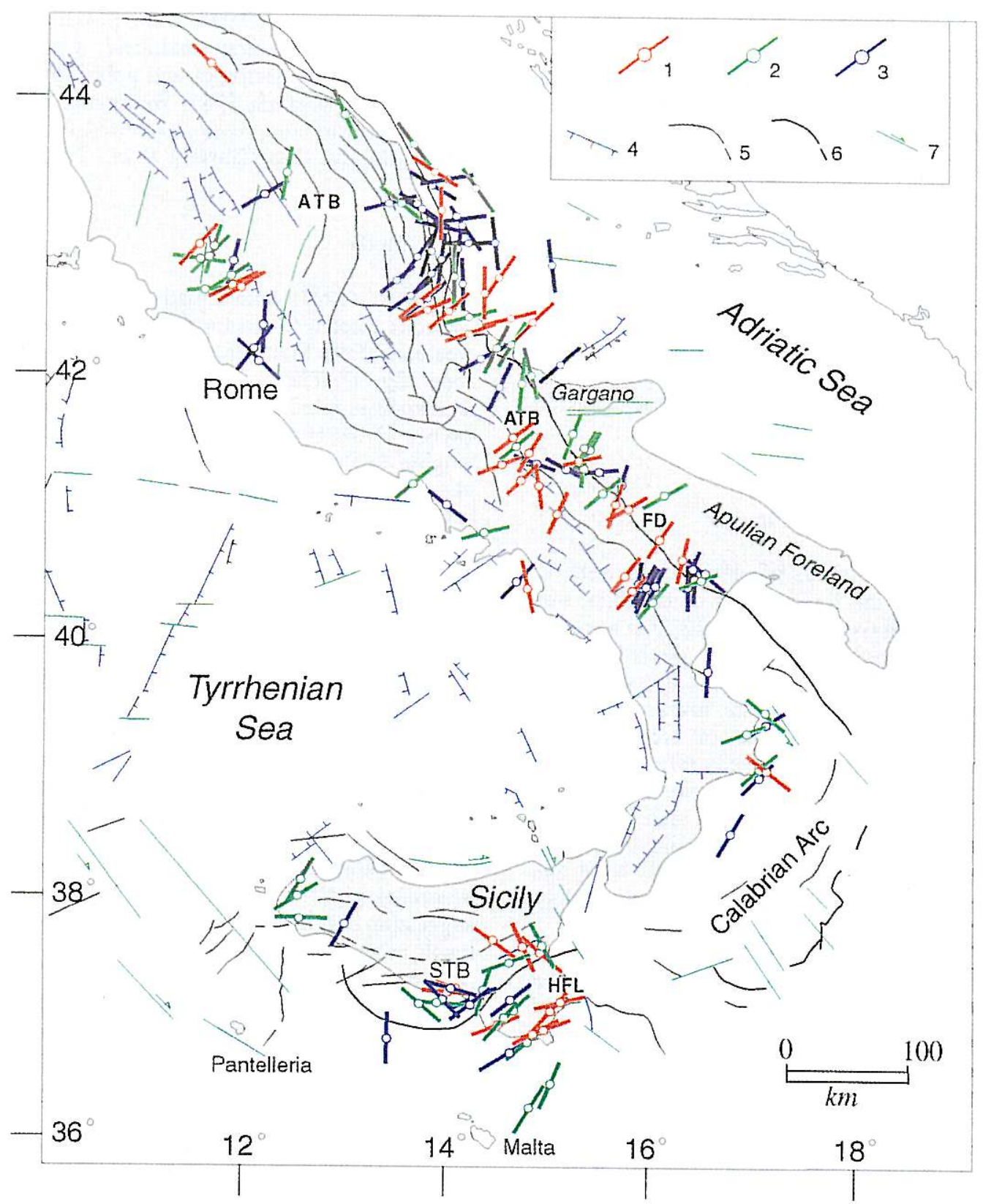

Fig. 4. $S_{h \min }$ directions from breakout analysis according to data quality. The $S_{h \min }$ directions in Sicily are from Cesaro (1993) and Ragg et al. (1995): 1) 'A' and 'B' quality; 2) 'C' quality; 3) 'D' quality; 4) normal faults; 5) major overthrusts of the Apennines; 6) front of the «plastic» allochthonous sheet in the Southern Apennines and Sicily; 7) strike-slip and undetermined faults. FD = Apenninic foredeep; ATB = Apenninic thrust belt zone; STB $=$ Sicily thrust belt zone; HFL $=$ Hyblean foreland. Tectonics modified from Patacca and Scandone (1987) and Bigi et al. (1990). 
Amato and Montone (1997). A NE-SW $S_{h \min }$ is evident throughout the southern peninsula, with a N40-50E $S_{h \min }$ in the belt, in agreement with the seismic deformation inferred from large earthquakes (NE-oriented extension, mostly accomplished on NW-SE trending normal faults). In the foredeep and foreland (Apulia), the results show $S_{h \min } \mathrm{N} 60-70 \mathrm{E}$, i.e. about $20^{\circ}$ clockwise rotated from the Apenninic trend. The seismicity in the foredeep region consists of a few, mostly strike slip, earthquakes that suggest a nearly vertical $\sigma_{2}$ (Amato et al., 1995). In the Adriatic plate, there are hints of isotropic horizontal stress, since no ovalizations were found in the few wells located offshore the Southern Adriatic.

\subsubsection{Ionian Calabria region}

From the analysis of eleven deep wells located along the Ionian coast of Calabria, only eight wells gave valuable results, two were discarded for problems with the deviation angle from the vertical (too large or too small) and another one for the unclear results, that show highly scattered directions of breakouts. The eight good wells are generally affected by large scatter of the breakout directions, and show different directions even at small distance. They are all located near the Ionian coast ( 3 on land and 5 offshore). All the wells were analyzed using both digital data and paper logs, with comparable results.

In the northern sector we found $S_{h \min }$ oriented $\sim \mathrm{NS}$, in agreement with focal mechanisms (see next section), although this result derives from only one well with ' $D$ ' quality, (fig. 4).

The central group exhibits two $S_{h \min }$ directions, perpendicular between each other. The first direction, roughly $\mathrm{NW}-\mathrm{SE}$, comes from two boreholes (data quality: ' $\mathrm{B}$ ' and ' $\mathrm{C}$ ') located more to the east with respect to the wells that gave NE-SW direction of $S_{h \text { min }}$. These are 4 wells with ' $C$ ' or ' $D$ ' qualities. Although the number of analyzed wells is low and the data quality is not very good, it appears that an abrupt change occurs around the Ionian coastal region. The different $S_{h \min }$ directions observed in this area may be related to the proximity of the transition between mainland Calabria, where extensional tectonics and uplifting dominates (Moussat et al., 1986; Westaway, 1993), and a region in compression, inferred from recent geological data (Ghisetti et al., 1982).

\subsubsection{Sicily}

Cesaro (1993) determined breakouts from 24 wells located in the foreland zone (Hyblean area and Malta Platform) and in the thrust belt zone (fig. 1). The $S_{h \min }$ direction of the foreland zone is relative to the Meso-Cenozoic sequence of the Hyblean carbonate platform, belonging to the northern margin of the African plate, whereas the $S_{h \text { min }}$ directions in the thrust belt zone are relative to both the underthrusted African plate and the overlying terrigenous Neogene successions.

The foreland zone (Hyblean area and Malta Platform) shows a unimodal NE-SW $S_{h \text { min }}$ direction (Cesaro, 1993), except for a N-S $S_{h \text { min }}$ direction detected in a single well located near the Pantelleria rift (fig. 4). Similar results were found by Ragg et al. (1995) for Sicily with a clear NW-SE $S_{H \max }$ in the Hyblean foreland region, and strong rotations in the foredeep region. The directions of maximum horizontal stress detected in the foreland (NW-SE) is roughly parallel to the main plate convergence, according to NUVEL-1 (De Mets et al., 1990), suggesting that the stress concentrates here as a result of the NW (or NNW) motion of Africa with respect to Eurasia.

Along the thrust belt margin, the stress pattern is more complex, the underthrusted African succession is in fact characterized by $S_{h \min }$ direction ranging between NE-SW (regional trend) and NW-SE (fig. 4). In the overlying Neogene succession, no uniform $S_{h \text { min }}$ direction is observed throughout the thrust belt zone. However it must be stressed that, along the same well, the two successions (underthrusted African units and overlying Neogene terrigenous units) are always characterized by different $S_{h \text { min }}$ directions (Cesaro, 1993).

The strong stress rotations observed in the thrust belt zone may be due to the interaction 
between the regional stress and local sources, such as the Pantelleria rift opening and/or the flexuring of the plate beneath the foredeep (Cesaro, 1993; Ragg et al., 1995).

\section{Seismicity}

\subsection{Data selection}

We analyzed 449 focal mechanisms of events recorded by the national seismic network of the ING in the period 1988-1995 (fig. 1). The magnitudes $M_{d}$ of these events range between 2.5 and 4.8 .

The earthquakes were located with the computer program HYPOINVERSE (Klein, 1989) using a gradient velocity structure. Focal solutions were determined with the FPFIT program (Reasenberg and Oppenheimer, 1985). Following a quality factor criteria, we selected 297 reliable focal mechanisms, among which 125 are of earthquakes which occurred in Northern Apennines, 64 in Southern Apennines, and 108 in Sicily (fig. 1).

The fault plane solutions were then classified in stress regime categories which are based on different plunge ranges for $P$ - and $T$-axes, following Zoback (1992) for the World Stress Map. Among the 297 computed focal mechanisms, only $16 \%$ are «oblique» (not referable to any stress category): this confirms that stresses in the upper crust are characterized by two horizontal principal stresses and the third on the vertical plane.

\subsection{Fault plane solutions}

In the Northern Apennines the most important result is the evident separation between an area characterized by normal (and subordinately strike-slip) faulting and one characterized by reverse (and strike-slip) faulting. Normal faulting solutions are distributed in a large portion of the Northern Apennines, while the reverse solutions are confined in a narrow belt, the Po plain-Adriatic compressional belt, which follows the curvature of the Northern Apenninic arc from Emilia to the Southern
Marche (fig. 5). The strike-slip solutions are spread almost everywhere, except in Central and Southern Tuscany (figs. 5 and 6). In the extensional area the $T$-axes of normal and strike-slip solutions have different orientations, with a prevalence of NE-SW to E-W trends, while in the compressional area the $P$-axes of thrust and strike-slip solutions have a predominant NE-SW direction. Results of stress inversion from earthquake data reveal a horizontal, NE-SW oriented $\sigma_{1}$ in this belt, with $\sigma_{2}$ close to vertical in the southern sector (RomagnaMarche), and plunging $60^{\circ}$ in the northern sector (Caorso-Emilia) (Frepoli and Amato, 1996). These results are in very good agreement with the distribution of horizontal stress directions inferred from breakouts.

In the Northern Apennines, the contemporaneous existence of active extension and compression revealed by active stress indicators is coherent with the geological observation of the eastward migration of the compressional front and the adjacent extensional back-arc region, observed since at least Miocene times (Patacca and Scandone, 1987; Vai, 1987).

Only extension perpendicular to the belt is observed in the Southern Apennines (fig. 6), in perfect agreement with the results of breakout analysis. $T$-axes of normal and strike-slip solutions are generally oriented NE-SW along the belt, as evident also from focal mechanisms of large earthquakes (Amato et al., 1995). In the Gargano sector, $T$-axes oriented E-W are predominant, while in Southern Calabria and the Messina Strait they are heterogeneously directed (fig. 6), although with a hint of rotation from a N-S trend in the north, to $\sim \mathrm{E}-\mathrm{W}$ near Sicily. This is consistent with a maximum horizontal stress rotating from E-W at the northern end of the Calabrian arc, to N-S at its southwestern end (NE-Sicily), consistently with the curvature of the arc itself and with the hypothesized active convergence at the outer front. Unfortunately, with the presently available data we cannot constrain the active stress field all around the Calabrian arc, both because the seismicity is too sparse (particularly in the Ionian side, where the network geometry is very unfavorable) and because the borehole data are not well distributed in the entire region. 


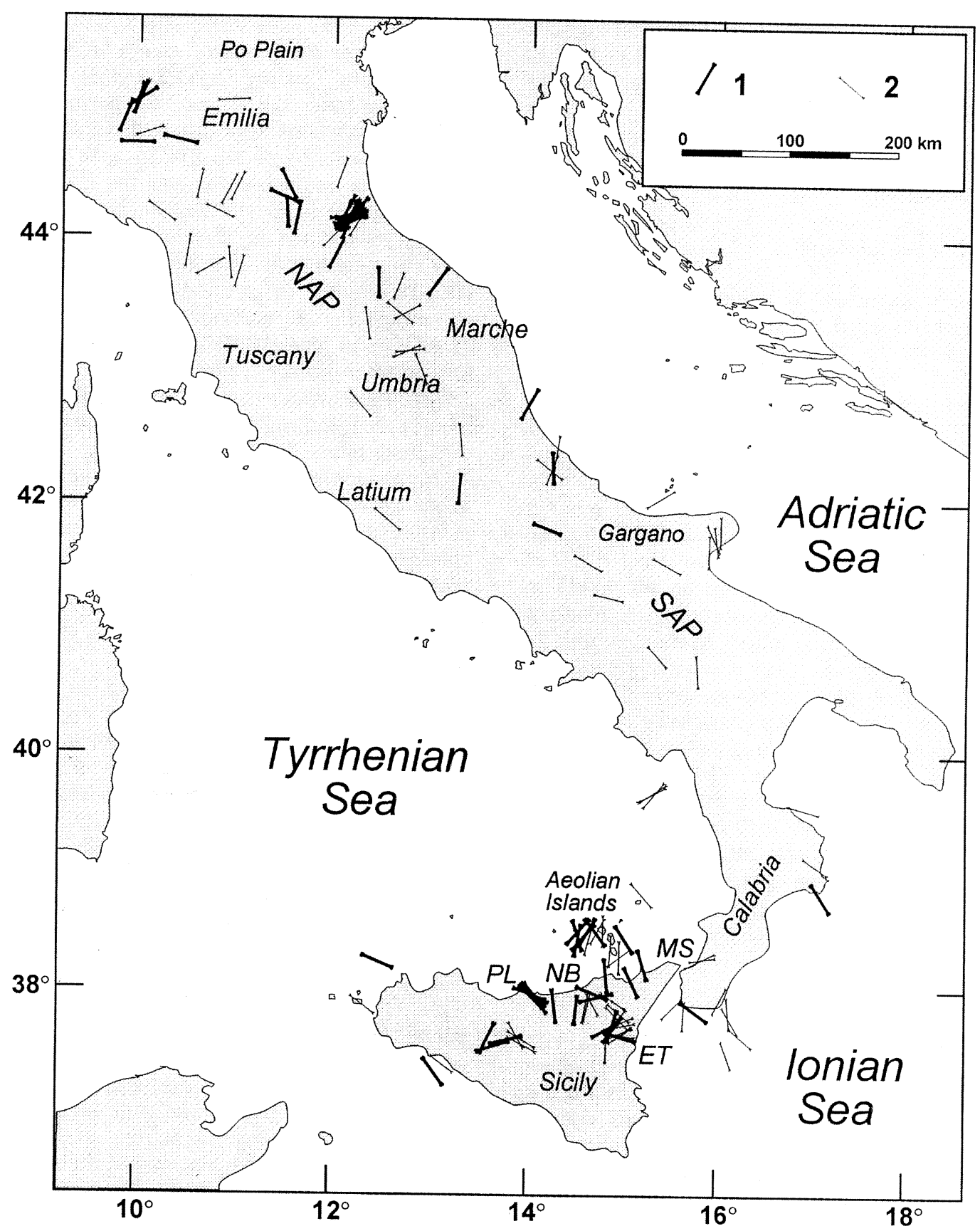

Fig. 5. $P$-axes distribution of (1) thrust- and (2) strike-slip fault-plane solutions in the period 1988-1995; NAP = Northern Apennines; SAP = Southern Apennines; ET = Etna sector; MS = Messina Strait; NB = Nebrodi Mts sector; PL = Pollina area. 


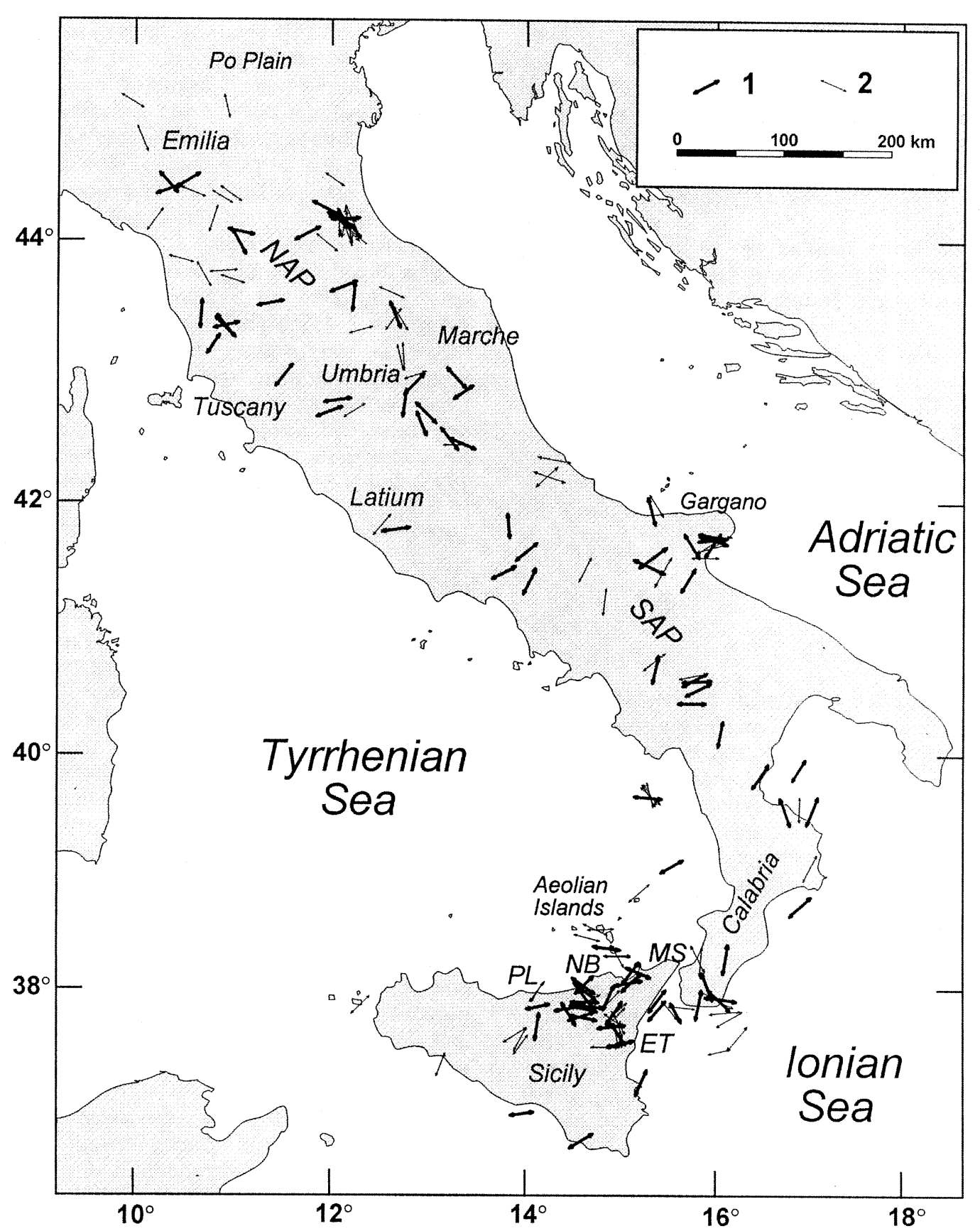

Fig. 6. T-axes distribution of (1) normal- and (2) strike-slip fault-plane solutions of earthquakes in the period 1988-1995; geographical indications are the same as in fig. 5. 
The E-W direction of the minimum horizontal stress obtained around the Messina Strait is in agreement with the extensional character of the Strait that might have been generated by repeated normal faulting earthquakes like the 1908, $M \sim 7$ Messina-Reggio Calabria earthquake (Valensise and Pantosti, 1992).

In Sicily, most of the analyzed events are concentrated in the north-eastern part of the island. Reverse faulting mechanisms are prevalent in the Aeolian Islands and in the Pollina area (fig. 5). In these two areas most of the $P$-axes are oriented approximately $\mathrm{N}-\mathrm{S}$ and NW-SE, respectively. Also the few thrust and strike-slip solutions of events located in Central and Western Sicily have $P$-axes oriented NW-SE. More heterogeneous is the distribution both in fault plane solution categories and axes orientation for the Nebrodi Mts. and Etna sectors.

\section{Discussion}

A detailed knowledge of the active stress field is necessary in order to constrain the active tectonic processes and the recent geodynamic evolution of the Italian region. The collection of hundreds of reliable stress indicators summarized in this paper allows us to shed light on some controversial points that have been the matter of discussion among earth scientists for many years. The main standing points of our research at the present stage are the following.

In Southern Italy, the direction of the maximum horizontal stress, $S_{H \max }$, is roughly parallel to the relative convergence between Africa and Eurasia as inferred from global plate motion studies (NUVEL-1, De Mets et al., 1990), although NUVEL-1 approximates the boundary between these two main plates as a roughly straight line crossing Northern Africa and Sicily, and does not take into account the strong curvature of the Calabrian-ApenninicAlpine belts. NUVEL-1 predicts a convergence $\sim \mathrm{N} 20^{\circ} \mathrm{W}$ in South-Eastern Sicily at $0.5-0.8$ $\mathrm{cm} / \mathrm{yr}$, consistently with results of VLBI observations in the Hyblean foreland (Ward, 1994).
Argus et al. (1989) obtained the NW to NNW Africa-Eurasia convergence around Sicily using only transform fault azimuths and 3 m.y. average spreading rates in the Atlantic, omitting slip vectors of earthquakes in the Gibraltar to Sicily section. Argus et al. (1989) also remark how the predicted convergence agrees with the slip vectors of thrust and strike-slip earthquakes in the region.

The directions of $S_{H \max }$ inferred from breakouts in the Hyblean foreland (Cesaro, 1993; Ragg et al., 1995) range between N50W and $\mathrm{N} 20 \mathrm{~W} ;$ i.e. only slightly rotated counter-clockwise from the plate motion direction. Data from earthquake focal mechanisms are in agreement with this pattern, indicating a NWSE compression in SE-Sicily (Amato et al., 1995) and N-S compression in Northern Sicily (Pondrelli et al., 1995; Frepoli and Amato, 1996). Therefore, we interpret the NNW direction of $S_{H \max }$ as the regional stress due to the Africa-Eurasia convergence.

This NNW to NW-oriented direction of maximum compression is detected in the entire northern margin of the African plate, west of Sicily (Zoback, 1992), and in Western Central Europe (Mueller et al., 1992), where a thrust or strike-slip stress regime with $\mathrm{NW} \sigma_{1}$ dominates. Around the Alpine belt, as well as in peninsular Italy, the stress directions are strongly affected by the presence of «secondary» features, such as the Adriatic microplate and the mountain belts with their crustal thickening and lithospheric «roots». The stress field around the Adria plate derives from the interaction between the main plate convergence and the collision and subduction processes acting along the Alpine, Apennines and Calabrian arcs. In the Alps, the $S_{H \max }$ directions are roughly perpendicular to the belt, ranging from N-S in the east (Friuli area) to NNW-SSE in Central Alps, and even stronger rotations $(\sim \mathrm{E}-\mathrm{W})$ in South-Western Alps. These directions are interpreted as due to the interaction between the N-S to NW-SE indentation of Adria under the Alps. The presence of thick lithospheric roots is thought to overcome the tension caused by high topography and thick crust, and to be responsible for additional E-W compression (Mueller et al., 1992). Grun- 
thal and Stromeyer (1992) modelled this with an increased rigidity of the Adriatic promontory, obtaining remarkable $S_{H \max }$ rotations, in agreement with the observed fan-shaped pattern of the Western Alps.

The NW-SE directions of $S_{H \max }$ measured from both breakouts and focal mechanism of earthquakes in the Apenninic belt are also compatible with the main plate convergence, but are associated with a normal faulting stress regime, as witnessed by focal mechanisms of strong earthquakes (Anderson and Jackson, 1987) and confirmed by the new data on focal plane solutions of small earthquakes presented here (fig. 6).

The total absence of thrust faulting mechanisms in the Southern Apennines confirms that the belt is currently undergoing extension and uplifting (see also Westaway, 1993; Pantosti et al., 1993; Hippolyte et al., 1995; Amato and Montone, 1997), and is in agreement with breakout data that show predominant NE-SW trending $S_{h \min }$. Even the foredeep region appears to be characterized by $S_{h \text { min }}$ perpendicular to the direction of the thrust front, including the most external sector that was undergoing NE-SW shortening until the middle Pleistocene, according to Scandone et al. (1996). However, it must be noted that the southernmost region of the foredeep shows more northerly directed $S_{h \min }$ directions. This stress rotation is possibly related to the proximity of the Ionian area, where seismic reflection profiles indicate active compression since the early Pleistocene along the allochthonous thrust front (Senatore, 1987).

The agreement among stress data obtained with different methodologies, observed globally (Zoback, 1992) and well evident in large sectors of Italy, is surprising if we consider that breakouts and focal mechanisms are relative to different depth intervals $(0-5-7 \mathrm{~km}$ for the former, $3-20 \mathrm{~km}$ for the latter), and to different structural units. In the Southern Apennines, data from Quaternary surface faults (Hippolyte et al., 1994) and seismological data are consistent with this pattern (Amato and Montone, 1997).

In order to assess whether the individual stress measurements bring information on the regional stress acting in a broad area, we compared the azimuthal distributions of two different data sets, namely: a) borehole breakouts, and b) extensional axes of earthquakes occurred from 1962 to 1995, with magnitude between 3 and 7, in the Southern Apennines (fig. 7a,b). To obtain a qualitative comparison between breakout inferred $S_{h \text { min }}$ directions and extensional axes directions, we computed the mean value that corresponds to the angular average of all the data, and the measure of dispersion for each data set.

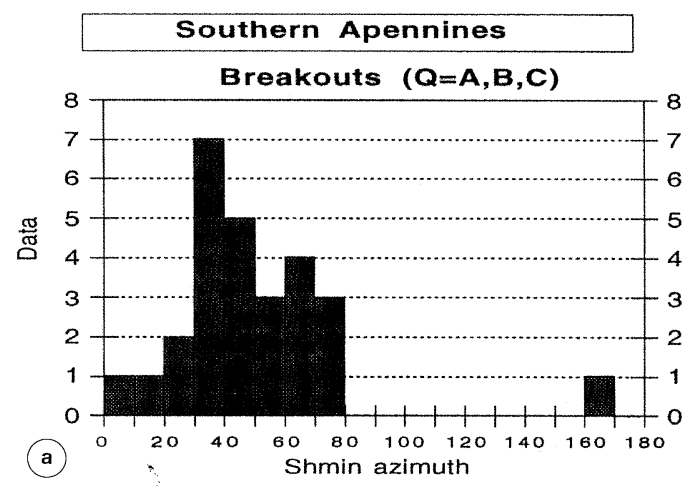

Earthquakes 1962-1995, $3<M<7$

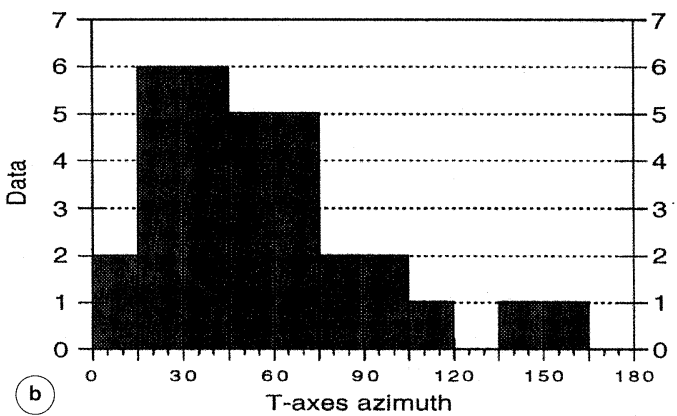

Fig. 7a,b. Azimuthal distribution of minimum horizontal stress directions in Southern Apennines. a) 27 $S_{h \min }$ directions from breakout analysis relative to wells with assigned A, B and C quality; b) 31 tension axes of earthquake focal mechanisms in the period 1962-1995, with $3<M<7$ from CMT solutions, Gasparini et al. (1985), and Frepoli and Amato (1996). The mean values of the two distributions are $\mathrm{N} 44^{\circ} \mathrm{E} \pm 20^{\circ}$ and $\mathrm{N} 44^{\circ} \mathrm{E} \pm 27^{\circ}$, respectively. 
We calculate the mean direction with the following formula (Davis, 1986):

$$
\theta=\operatorname{arctang}\left(\Sigma_{i=1}^{n} \sin \theta_{i} / \Sigma_{i=1}^{n} \cos \theta_{i}\right)
$$

and the dispersion $R$ :

$$
R=\frac{\sqrt{\left(\sum_{i=1}^{n} \sin \theta_{i}\right)^{2}+\left(\sum_{i=1}^{n} \cos \theta_{i}\right)^{2}}}{n}
$$

In order to have a measure of dispersion which increases with increasing scatter, we report its complement, called the circular variance $(1-R)$. The circular variance, in degrees, is obtained from:

$$
\sigma=[0.5 \sqrt{2 \cdot(1-R)}] \cdot \frac{180}{\pi}
$$

The two distributions are very similar to each other, with average $S_{h \min }$ directions of $\mathrm{N} 44^{\circ} \mathrm{E} \pm 20^{\circ}$ and $\mathrm{N} 44^{\circ} \mathrm{E} \pm 27^{\circ}$ for (a) and (b), respectively. In our opinion, this demonstrates that the measured values are representative of the regional stress, and the deviations from the mean value can be seen as rotations due to «local» sources.

Compared to the Southern Apennines, the northern arc is characterized by a drastically different stress distribution (Mariucci et al., in preparation). North of $43^{\circ} \mathrm{N}$, both breakout data and focal mechanisms reveal horizontal compression perpendicular to the thrust front ( $\sigma_{1}$ oriented NE-SW) in the external sector of the arc. Around this latitude, a drastic change in the stress distribution is observed. Rotations of as much as $90^{\circ}$ are detected from breakout results in deep wells of the external sector of the Northern Apenninic arc (fig. 4), with directions of $S_{h \min }$ ranging from NE-SW in the south, to N-S mainly in the Central Adriatic offshore, up to NW-SE north of $43^{\circ}$, consistent with a $\sim$ NE-SW maximum horizontal stress. The distribution of thrust faulting earthquakes in the Apennines is consistent with this stress direction, in fact almost all the reverse faulting mechanisms of the Apennines are located north of $43^{\circ} \mathrm{N}$ (fig. 5). The compressional belt is narrow $(\sim 30-50 \mathrm{~km})$, and lies adjacent to a broader internal sector, extending throughout
Tuscany, Umbria and Latium, characterized by $\sim$ ENE extension, accomplished by normal and strike-slip faulting earthquakes. Similar results were obtained by Montone et al. (1995) for the volcanic province of Latium and Southern Tuscany.

The «compressional» front depicted from active stress data, following the northern arc from northwest to southeast down to latitude $\mathrm{N} 43^{\circ}$, matches fairly well the Po plain-Adriatic compressional belt outlined by the front of the thrust sheets (Scandone et al., 1996).

Moreover, the extent of this region seems to be related to the deep structures and the subcrustal seismicity (Montone et al., 1996). A striking correspondence is in fact observed among stress directions in the upper brittle crust and geometry of the lithospheric slabs hypothesized from seismic tomography and deep earthquake distribution. Amato et al. (1993) point out the existence of a strong high velocity anomaly in the upper $200-300 \mathrm{~km}$ beneath this region, that is interpreted as a remnant of the Adriatic lithosphere currently sinking beneath the Northern Apenninic arc. This high velocity body is apparently continuous with the shallow part of the Adriatic lithosphere, as indicated by the distribution of subcrustal earthquakes that deepen from east to west down to $90 \mathrm{~km}$ depth (Selvaggi and Amato, 1992). These anomalously deep earthquakes are located only below the northern arc, and are not present beneath the Central-Southern Apennines (fig. 1), suggesting that the hypothesized subducting slab is either detached or thermally assimilated in Central and Southern Italy. Accordingly, the tomographic images of the upper mantle show that the Apenninic high velocity anomaly becomes weaker and may be deeper south of latitude $\mathrm{N} 42^{\circ}-\mathrm{N} 43^{\circ}$ approximately (Amato et al., 1993; Cimini and De Gori, 1997).

A possible speculative mechanism that can be proposed at this stage is therefore that the active compression in the northern arc is due to the action of a still active (or passively sinking) lithospheric slab, that also generates extension in the back-arc region. This would explain the migration of the extension - compression pair through time. 
In the Central-Southern Apennines, a thermal episode might have determined the assimilation of the slab, causing a reduction in the downward directed forces exerted by the dense sinking slab, the uplift of the belt, and the diffuse extension perpendicular to the Apennines, as observed from breakouts and focal mechanisms.

Modelling the complex forces acting in this region is therefore becoming more and more important to constrain the active tectonic processes. We believe that the detailed knowledge of the stresses involved in such processes would greatly contribute to discriminate among the numerous possible mechanisms governing the recent geologic evolution of the Italian region.

\section{Conclusions}

A reliable map of the active stress in Italy will be available soon. When complete, it will serve as a basic tool for many research fields in Earth science. Among these, the most relevant are to constrain and understand better the forces that are deforming the Italian region; and to contribute to seismotectonic zoning and seismic hazard assessment.

In regions like Italy, where active tectonic processes are relatively slow, many parameters that are needed to understand the active tectonic processes and to constrain numeric models that are not known yet (for instance, strain rates from geodetic data). An accurate knowledge of the stress field is therefore extremely important to constrain such models and to understand the forces acting in our region. A first-order goal that we are pursuing is to discriminate between the contribution of the main plate convergence and the buoyancy forces related to active and past subduction and collision processes. The stress field distribution presented here highlights the importance of plate convergence in Southern Italy (Sicily), where the maximum horizontal stress parallels the Africa-Eurasia relative motion, and in the Alpine region, where the indentation of Adria generates a fan-shaped pattern of maximum compressive stress.
Other forces determine the present-day state of stress along the Italian peninsula, most of which are related to the westward subduction of the Ionian/Adriatic lithosphere beneath the Apennines. Here, the correspondence between the stress regime in the brittle upper crust and the structures outlined by seismicity and tomography, suggests a tight (though not straightforward) relationship between them. In particular, where there is evidence of a continuous slab in the upper $200-300 \mathrm{~km}$, we find an active compressional front from stress data (Northern Apennines, and possibly Calabria). On the contrary, the Southern Apennines, where there is evidence of a detached (or a less dense) slab are characterized by extension. This may be due to the (delayed) effect of the detachment, or to thermal assimilation of the slab with the consequent diminution of forces acting on it.

A detailed map of the present-day stress field is also important for seismic hazard evaluation, since it may tell us which faults are more likely to rupture in future earthquakes, and with which mechanism. This is particularly important in regions where active faults have no surface expression, and this is a very frequent case in Italy, both because repeat times of earthquakes are large (often thousands of years), and because many moderate but hazardous earthquakes $(M<6.5)$ occur on blind faults. The integration of stress data with seismicity patterns determined from instrumental monitoring and historical information broaden our possibility of assessing seismic hazard in Italy.

\section{Acknowledgements}

This paper would not have been possible without AGIP S.p.A. data: we are grateful to Dr. Frigoli and Dr. Gabbi for their collaboration. We are also grateful to E. Boschi for his continuous encouragement to carry out this research. The paper has benefited from reviews of A. Barka and an anonymous referee. Comments from E. Mantovani are also appreciated. All the seismic data derive from the National Seismic Network of ING. This work was partially supported by EC contract EV5V-CT940464. 


\section{REFERENCES}

Amato, A. and P. Montone (1996): Present-day stress field and active tectonics in Southern Peninsular Italy, Geophys. J. Int., 130 (in press).

Amato, A., B. Alessandrini, G.B. Cimini, A. Frepoli and G. Selvaggi (1993): Active and remnant subducted slabs beneath Italy: evidence from seismic tomography and seismicity, Annali di Geofisica, 36 (2), 201-214.

Amato, A., P. Montone and M. Cesaro (1995): State of stress in Southern Italy from borehole breakout and focal mechanism data, Geophys. Res. Lett., 22 (23), 3119-3122 .

ANDERSON, E.M. (1951): The Dynamics of Faulting, 2nd edition (Oliver and Boyd, Edinburgh), pp. 206.

ANDERSON, H.J. and J.A. JACKSON (1987): Active tectonics of the Adriatic region, Geophys. J. R. Astron. Soc., 91, 937-983.

Argus, D.F., R.G. Gordon, C. DeMets and S. Stein (1989): Closure of the Africa-Eurasia-North America plate motion circuit and tectonics of the Gloria fault, J. Geophys. Res., 94 (B5), 5585-5602.

BASSI, G. and R. SABADINI (1994): The importance of subduction for the modern stress field in the Tyrrhenian area, Geophys. Res. Lett., 21 (5), 329-332.

Bell, S. and D.I. Gough (1983): The use of borehole breakouts in the study of crustal stress, in Hydraulic Fracturing Stress Measurements, edited by M.D. ZoBACK and B.C. HAIMSON (National Academy Press, Washington, D.C.), 201-209.

Bigi, G., D. Cosentino, M. Parotto, R. Sartori and P. SCANDONE (1990): Structural Model of Italy, 1:500000, PFG-CNR, Quad. Ric. Sci., 114.

Cesaro, M. (1993): Campo di stress da studi di breakout: analisi e modello interpretativo, Pubblicazione Interna AGIP, pp. 107.

Cimini, G.B. and P. DE Gori (1997): Upper mantle velocity structure beneath Italy from direct and secondary $P$ wave teleseismic tomography, Annali di Geofisica, 40, 175-194.

Davis, J.C. (1986): Statistics and Data Analysis in Geology, 2nd edition (J. Wiley and Sons, New York), pp. 646.

De Mets, C., R.G. Gordon, D.F. Argus and S. Stein (1990): Current plate motions, Geophys. J. Int., 101, 425-478.

Faccenna, C., P. Davy, J.P. Brun, R. Funiciello, D. Giardini, M. Mattei and T. Nalpas (1996): The dynamics of back-arc extensions: an experimental approach to the opening of the Tyrrhenian Sea, Geophys. J. Int., 126, 781-795.

Frepoli, A. and A. AMATO (1996): Microseismotectonic analysis of the Italian region: new data for geodynamics modeling, EGS Abstracts, Annales Geophysicae, suppl. 1, 14, C81.

Frepoli, A. and A. Amato (1997): Contemporaneous extension and compression in the Northern Apennines from earthquake fault-plane solutions, Geophys. J. Int., 129 (in press).

Frepoli, A., A. Amato and C. Chiarabba (1993): Studio di meccanismi focali di alcuni terremoti italiani recenti, in Proceedings 12th Meeting of the «Gruppo Nazionale di Geofisica della Terra Solida», CNR, Roma, Italy, 217-226.

Gasparini, C., G. IAnNacCone and R. Scarpa (1985): Fault-plane solutions and seismicity of the Italian peninsula, Tectonophysics, 117, 59-78.

GhisetTI, F., R. ScARPa and L. VEZZANi (1982): Seismic activity, deep structures and deformation processes in the Calabrian arc, Southern Italy, Earth Evol. Sci., 3, 248-260.

Giunchi, C., R. Sabadini, E. Boschi and P. Gasperini (1996): Dynamic models of subduction: geophysical and geological evidences in the Tyrrhenian, Geophys. J. Int., 126, 555-578.

Grunthal, G. and D. Stromeyer (1992): The recent crustal stress field in Central Europe: trajectories and finite element modeling, J. Geophys. Res., 97 (B8), $11805-11820$

Hippolyte, J.C., J. ANGelier and F. Roure (1994): A major geodynamic change revealed by Quaternary stress patterns in the Southern Apennines (Italy), Tectonophysics, 230, 199-210.

Hippolyte, J.C., J. ANGelier and E. BARRIER (1995): Compressional and extensional tectonics in an arc system: example of the Southern Apennines, J. Struct. Geol., 17 (12), 1725-1740.

JACKSON, J. and D. MCKEnZIE (1988): The relationship between plate motions and seismic moment tensor, and rates of active deformation in the Mediterranean and the Middle East, Geophys. J. R. Astron. Soc., 93, 45-73.

KLEIN, F.W. (1989): Hypoinverse, a program for Vax computers to solve for earthquake location and magnitude, USGS Open File Rep., 89-314, 6/89 version.

MCGARR, A. and N.C. GAY (1978: State of stress in the Earth's crust, Ann. Rev. Earth Planet. Sci., 6, 405-436.

Montone, P., A. Amato, R. Chiulli and R. Funiciello (1992): Metodologie per la determinazione del campo di stress attuale da dati di perforazioni profonde, in Proceedings 11th Meeting of the «Gruppo Nazionale di Geofisica della Terra Solida», CNR, Roma, Italy, 337-348.

Montone, P., A. Amato, C. Chiarabba, G. BuonaSORTE and A. FIORDELISI (1995): Evidence of active extension in Quaternary volcanoes of Central Italy from breakout analysis and seismicity, Geophys. Res. Lett., 22 (14), 1909-1912.

Montone, P., A. Amato and M.T. Mariucci (1996): The state of stress in the Italian peninsula, EGS Abstracts, Annales Geophysicae, suppl. 1, 14, C83.

Moussat, E., J. Angelier, G. Mascle and J.P. RéHault (1986): L'ouverture de la Mer Tyrrhénienne et la tectonique de faille néogène quaternaire en Calabre, G. Geol., 3 (48/1-2), 63-75.

Mueller, B., M.L. Zoback, K. Fuchs, L. Mastin, S. Gregersen, N. Pavoni, O. Stephansson and C. LJUNGGREN (1992): Regional patterns of tectonic stress in Europe, J. Geophys. Res., 97, 11783-11803.

Pantosti, D., D.P. Schwartz and G. Valensise (1993): Paleoseismology along the 1980 Irpinia earthquake fault and implications for earthquake recurrence in the Southern Apennines, J. Geophys. Res., 98, 65616577. 
PAtaccA, E. and P. ScAndone (1987): Post-Tortonian mountain building in the Apennines: the role of the passive sinking of a relic lithospheric slab, in The Lithosphere in Italy: Advances in Earth Science Research, edited by A. BORIANI, M. BONAFEDE, G.B. PICCARDO and G.B. VAI, Accademia Nazionale dei Lincei, Mid Term Conference, Rome 5-6 May, 1987, 157-176.

Plumb, R.A. and S.H. HickmanN (1985): Stress-induced borehole elongation: a comparison between dipmeter and the borehole televiewer in the Auburn geothermal well, J. Geophys. Res., 90, 5513-5521.

Pondrelli, S., A. Morelli and E. Boschi (1995): Seismic deformation in the Mediterranean area estimated by moment tensor summation, Geophys. J. Int., 122, 938-952.

RaGG, S., M. Grasso and B. Mueller (1995): 3-D FE computation of tectonic stresses in Sicily combined with results of breakout analysis, Terra Nova, 7 (abstract suppl. 1), 170.

REASENBERG, P.A. and D. OPPEnHEIMER (1985): Fortran computer programs for calculating and displaying earthquake fault-plane solutions, USGS Open file Rep., 85-739, pp. 109.

Rebai, S., H. PhiliP and A. TABoada (1992): Modern tectonics stress field in the Mediterranean region: evidence for variation in stress directions at different scales, J. Geophys. Res., 110, 106-140.

SelvagGi, G. and A. Amato (1992): Subcrustal earthquakes in the Northern Apennines (Italy). Evidence for a still active subduction?, Geophys. Res. Lett., 19, 2127-2130.
Senatore, M.R. (1987): Caratteri sedimentari e tettonici di un bacino di avanfossa. Il Golfo di Taranto, Mem. Soc. Geol. It., 38, 177-204.

Scandone, P., E. Patacca and C. Meletti (1996): Main recent deformation and seismotectonics in the Central Mediterranean region, in Workshop on Geodynamics of the Mediterranean Area and Implications on Volcanic and Seismic Hazards, International School Earth and Planetary Sciences, 1-4/04/1996.

VAI, G.B. (1987): Migrazione complessa del sistema fronte deformativo-avanfossa-cercine periferico: il caso dell'Appennino Settentrionale, Mem. Soc. Geol. It., 38, 95-106.

VAlensise, G. and D. Pantosti (1992): A 125 kyr-long geological record of seismic source repeatability: the Messina Straits (Southern Italy) and the 1908 earthquake $\left(M_{s} 71 / 2\right)$, Terra Nova, 4, 472-483.

WARD, S.N. (1994): Constraints on the seismotectonics of the Central Mediterranean from very long baseline interferometry, Geophys. J. Int., 117, 441-452.

WestaWAy, R. (1987): The Campania Southern Italy, earthquakes of 21 August 1962, Geophys. J. R. Astron. Soc., 88, 1-24.

WESTAWAY, R. (1993): Quaternary uplift of Southern Italy, J. Geophys., Res., 98, 21741-21772.

ZOBACK, M.L. (1992): First- and second order patterns of stress in the lithosphere: the World Stress Map Project, J. Geophys. Res., 97, 11703-11728.

ZoBACK, M.L. (1993): Utilizing in-situ stress data for seismic hazard assessment: the World Stress Map Project's contribution to GSHAP, Annali di Geofisica, 36 (3-4), 217-224. 